1 Sanders A, Criss E, Steckl P, Meislin H, Raife J, Allen D. An analysis of medical care at mass gatherings. Ann Emerg Med 1986;15:515-9.

2 Guide to safety at sports grounds. 4th ed. London: Stationery Office, 1997.

3 Illinois State Medical Society. Guidelines for the provision of medical care at large scale events. ISMS: Illinois, 1984.

4 Baker W, Simone B, Niemann J, Daly A. Special event medical care: the 1984 Los Angeles Summer Olympics. Ann Emerg Med 1985;15:185-90.

5 Russell R. Hodgetts TJ, Castle N. Medical support to an organised rave. Pre-hospital Immediate Care 1999;3:5-10.

6 Pierce JMT, Clouter CA, Sanders M. Attendances at the medical centre at an internatonal guide and scout camp: the implications for future events. Pre-hospital Immediate Care 1998;2:71-3.

7 Hewitt S, Jarrett L, Winter B. Emergency medicine at a large rock festival. J Accid Emerg Med 1996;13:26-7.

8 Wong Tai-Wong, Yeung SSM, Lit C-H. Two mass sports events at Tsing Ma Bridge. Pre-hospital Immediate Care 1999:3:2-4.:
9 Kerr G,Jackson A, Parke T. The dangers of taking "T in the park." Scot Med J 1996;41:165-6.1

10 The winners at Wembley. Civil Protection 1996;40:6

11 Spaite D, Criss E, Valenzuela T, Meislin H, Smith R, Nelson A, et al. A new model for providing prehospital medical care in large stadiums. Ann Emerg Med 1988;17:825-8.

12 Kassanoff I, Whaley W, Walter W, Burge D, Harrison C, Hurst J, et al. Stadium coronary care: a concept in emergency health care delivery. JAMA 1972;221:397-9.

13 O'Donnell J, Gleeson A, Smith H. Edinburgh's Hogmanay celebrations: beyond a major disaster.J Accid Emerg Med 1998;15:272-3.

14 Hadden W, Pumford N. Medical cover for "The Open" golf championship. Br J Sp Med 1992;26:125-7.

15 Leonard R. Medical support for mass gatherings. Emerg Med Clin N America 1996:14:383-97.

\title{
Will the NHS pay awards help recruitment?
}

\author{
Not on their own
}

$\mathrm{M}$ uch has been made of the plight of NHS employees, ranging from observations on falling pay relative to other sectors, low morale, and severe recruitment and retention problems. The restructuring of the methods of pay setting, an ageing population, and a deteriorating public image of the NHS have all contributed to the problems the NHS has faced as an employer in recent years. Will the above inflation pay awards to health professionals, implemented this month, have eased these problems?

The pay review bodies have been central to the problem, as the last government in effect used them to facilitate the decentralisation of pay determination to local level. Some industrial relations experts have argued that this, together with the lack of extra government funding, has been key to the pay inequities and industrial relations problems in the NHS. ${ }^{1}$

The Labour government has recently accepted in full the recommendations of the pay review bodies, which do make a start at attempting to address these pay and employment problems. These pay awards, the first in five years to not be staged, give NHS employees their largest pay rises for 10 years: nurses, midwives, and health visitors have been awarded a $5 \%$ increase in pay; hospital doctors and general practitioners have been awarded lower increases, but still above inflation. Importantly, newly qualified nurses have seen their starting salaries raised by $12 \%$, up to an annual salary of $£ 14400$. Indeed, no other public sector group has done as well.

Is this enough to offset the staffing problems the NHS faces? The pay awards probably form a good starting point, but by themselves they are not enough. The awards should address some of the pay inequities embedded within NHS pay structures, but there is some way to go to reverse the longer term pay declines (relative to other sectors) that underpin the NHS's staff problems. Recruitment difficulties may well be tempered by the increase in starting salaries for nurses as this brings them almost in line with entry salaries into teaching.

But the other side of the recruitment-retention coin-that of keeping workers in the NHS-is unlikely to be significantly affected. For example, a survey in December 1998 by Incomes Data Services showed that over $90 \%$ of NHS trusts reported difficulties in recruiting and retaining staff in the year preceding the survey. ${ }^{2}$ This year's pay awards are unlikely to be sufficient to circumvent and cure problems on such a scale as this. The awards do have their merits-and something clearly had to be done-but a longer term commitment to resolving the pay and employment problems for all types of NHS employees would inevitably have had a bigger impact.

Another, and contrary, concern is whether such big pay awards to public sector workers are likely to have inflationary consequences. Predictable responses came from some commentators, such as tabloid journalists and some NHS trust managers, stating that these awards could signal the beginning of an inflationary spiral triggered off by such public sector pay awards. Yet productivity (measured by a range of indicators such as five star performance in league tables, falling average waiting times, and improved patient care) seems to have risen in the NHS in recent years. And standard economics tells us that productivity improvements are commensurate with increased pay awards.

The government's decision to raise the pay of nurses-particularly at entry level-is sensible in the context of the severe staffing problems faced by the NHS. But much damage has been done by the cumulative relative decline in pay and loss of staff of the past 10-15 years. Over and above this, the public's perception of nursing jobs and the NHS as a whole has altered dramatically. It is likely to take much more than a single pay rise to change this and make nursing an attractive job again. Given that the ageing of the population in Britain makes the demand for high quality workers in the nursing professions more acute, it is time for some more thoughtful workforce planning.

Stephen Machin Professor of economics, University College, and director

Industrial Relations Programme, Centre for Economic Performance, London School of Economics, London WC2A 2AE

1 Thornley C. Contesting local pay: the decentralisation of collective bargaining in the NHS. British Journal of Industrial Relations 1998;36: 413-34.

2 Incomes Data Services. Public Sector Labour Market Survey 1998. IDS Report 775, December 1998. 